- e ISSN-0976-6855 | Visit us : www.researchjournal.co.in

\title{
Effect of biorationals against the thrips, Scirtothrips dorsalis Hood infesting chilli
}

\author{
A. RAVIKUMAR, C. CHINNIAH*, S. MANISEGARAN, S. IRULANDI ${ }^{1}$ AND P. MOHANRAJ ${ }^{2}$ \\ Department of Agricultural Entomology, Agricultural College and Research Institute, MADURAI (T.N.) INDIA \\ ${ }^{1}$ Krishi Vigyan Kendra, PECHIPARAI (T.N.) INDIA \\ ${ }^{2}$ Directorate of Extension Education, Tamil Nadu Agricultural University, COIMBATORE (T.N.) INDIA
}

\section{ARITCLE INFO}

Received : 06.02 .2016

Revised : 21.02 .2016

Accepted : 03.03 .2016

KEY WORDS :

Biorationals, Thrips, LCI, Yield, Chilli

*Corresponding author:

Email: chinnaento@gmail.com

\section{ABSTRACT}

The present investigation was carried out to test the efficacy of biorationals against thrips, Scirtothrips dorsalis Hood on chilli. Field experiments were conducted at farmers holding during September 2009 - Febrauary 2010 and November 2009 - April 2010. Among biorationals tested, spinosad 45 SC @ 0.4 $\mathrm{ml} \mathrm{l}^{-1}$ and emamectin benzoate 5 SG @ $0.4 \mathrm{~g} \mathrm{l}^{-1}$ was found to be superior to the standard check dimethoate $30 \mathrm{EC} @ 2 \mathrm{ml} \mathrm{1}^{-1}$ registering the least population of 0.55 and 0.59 / leaf, followed by Beauveria bassiana @ $1 \times 10^{8}$ spores $\mathrm{ml}^{-1}$ and neem oil 3 per cent which recorded thrips population of 1.01 and 1.11 / leaf. With regard to leaf curl damage by thrips, spinosad 45 SC @ $0.4 \mathrm{ml} \mathrm{l}^{-1}$ and emamectin benzoate $5 \mathrm{SG} @ 0.4 \mathrm{~g} \mathrm{l}^{-1}$ was very effective. Highest dry chilli yield of 1509 $\mathrm{kg} \mathrm{ha}^{-1}$ was registered in spinosad $45 \mathrm{SC} @ 0.4 \mathrm{ml} \mathrm{l}^{-1}$, which was on par with emamectin benzoate $5 \mathrm{SG} @ 0.4 \mathrm{~g} \mathrm{l}^{-1}\left(1525 \mathrm{~kg} \mathrm{ha}^{-1}\right)$ with respective additional income of Rs. 30,300 and Rs. 26,400. The highest cost benefit ratio (1:4.30) was obtained in spinosad $45 \mathrm{SC}$ @ $0.4 \mathrm{ml}^{-1}$ followed by 1:4.30 in emamectin $5 \mathrm{SG} @ 0.4 \mathrm{~g} \mathrm{l}^{-1}$.

How to view point the article : Ravikumar, A., Chinniah, C., Manisegaran, S., Irulandi, S. and Mohanraj, P. (2016). Effect of biorationals against the thrips, Scirtothrips dorsalis Hood infesting chilli. Internat. J. Plant Protec., 9(1) : 158-161. 